\title{
THE CRITIQUE OF VERNACULAR DISCOURSE
}

\section{KENT A. ONO AND JOHN M. SLOOP}

Critical rhetoricians should, by criticizing vernacular discourse, follow the path of those who have discussed the rhetoric of the oppressed. The critique of powerful discourse has broad "historical" impact and therefore has been the primary mode of critique within rhetorical criticism. In addition to the critique of widely disseminated texts, critics should examine texts that profoundly influence vernacular communities and communitas. We conceptualize how a study of vernacular discourse could be carried out by defining vernacular, describing the critique of vernacular discourse, explaining the purpose of such criticism, and illustrating our approach through a brief study of one example of vernacular discourse: World War II representations of women in the Pacific Citizen, a Japanese American newspaper.

$I^{\prime}$ f one thing has remained a consistent practice in rhetorical criticism at least since Kenneth Burke's (1957) "The Rhetoric of Hitler's 'Battle,'" it is a critical focus on the discourse of the empowered, discourse of those who control, design, and create the public space. Burke did not study what homosexuals and Jews in the United States were saying about the Nazi movement in Germany. He did not look at the discourse of those in Germany who resisted or protested Hitler's rule. Burke's study is compelling because it indicts Hitler's rhetoric; it challenges the voice of oppression, villainy, martyrdom, and demagoguery in Mein Kampf. Burke was interested in rhetoric of the inhuman, the brutal, and the obsessed. His focus on Hitler's rhetoric is what makes his essay exemplary rhetorical criticism. Indeed, some might say that Burke's focus on power defines what rhetorical critics do: examine speeches of those who caused grave injustices and altered history as a result. For these scholars, the critique of power illuminates how power functions, how it controls.

However, the focus on evil power is not the only way to study power. Praiseworthy discourse, such as Martin Luther King Jr.'s (1963) "I Have a Dream" speech or Abraham Lincoln's (1863) Gettysburg Address, are often objects of study because they should be remembered, admired, and perhaps emulated. The rhetor learns how to make arguments, and through emulation speaking and writing become clearer. ${ }^{1}$ Thus, documents of power have been both deconstructed and emulated in the history of rhetorical criticism. But if we limit our attention to such documents available to the widest possible audience, documents that shaped the "history" of our society, then we are missing out on, and writing "out of history," important texts that gird and influence local cultures first and then affect, through the sheer number of local communities, cultures at large. Burke made the choice to analyze Hitler's rhetoric rather than the rhetoric of Jews in Warsaw or Berlin. He made a choice to criticize the man in control, not those buckling under his fist. We argue in this essay that rhetoricians-or more specifically, critical rhetoricians ${ }^{2}$ - should, by criticizing

Kent Alan Ono is assistant professor of rhetoric and communication at the University of California, Davis. John Martin Sloop is assistant professor of speech communication at Drake University. Portions of this manuscript were drawn from Kent Ono's doctoral dissertation (Iowa, 1992), Bruce Gronbeck (director). A version of this manuscript was presented at the Speech Communication Association Convention in New Orleans, LA, 1994. We would like to thank Todd Boyd, Sarah Projansky and Carole Blair for their help on this manuscript. 
vernacular discourse, follow the path of those who have discussed the rhetoric of the oppressed. ${ }^{3}$

From one perspective, vernacular discourse is speech that resonates within local communities. This discourse is neither accessible in its entirety, nor is it discoverable, except through texts. However, vernacular discourse is also culture: the music, art, criticism, dance, and architecture of local communities. In addition to being discourse operating within local communities rather than speeches preserved in history textbooks, vernacular discourse is unique to specific communities. Hence, as critics of vernacular discourse, we would not look at what the The New York Times had to say about rapper Ice T's new album; we would not look for reprinted speeches by Asian Americans on the pages of the Los Angeles Times. Critics of vernacular discourse would look at discourse that resonates within and from historically oppressed communities. This is not to say that localized communities, generally, should not be studied, but that there is a specific need, given historical power relations, to study communities that have been systematically ignored. Often this means looking at Asian American, African American, Latina, Latino, Native American, Lesbian, Gay, and European American feminist newspapers, periodicals, radio broadcasts, and television shows. At other times, it means reading pamphlets printed by community organizations, watching films by independent filmmakers, or talking about orations given on the street. Finally, the critique of vernacular discourse entails engaging in talk about everyday speech, conversations in homes, restaurants, and "on the corner."

We admit that the critique of powerful discourse has broad "historical" impact, and therefore has been the primary mode of critique within rhetorical criticism. Contemporary scholars have even gone so far as to advocate deconstruction of powerful discourse in order to lessen its effectiveness through its becoming "minor" (Deleuze \& Guattari, 1986). But the critique of widely disseminated texts has been done without the additional examination of texts that have profound effects on vernacular communities and have widespread effects on the communitas. Our purpose is to theorize a practice of examining vernacular discourse, explain the purpose of doing such criticism, and attempt to make good on our theory. Specifically, we will conceptualize how a study of vernacular discourse could be carried out by defining vernacular, describing the critique of vernacular discourse, and illustrating our approach through a brief study of one example of vernacular discourse: World War II representations of women in the Pacific Citizen, a Japanese American newspaper. ${ }^{4}$

In short, what we call for and describe is the construction, analysis, and consideration of the vernacular that has been to a large degree absent in scholarly rhetorical works. We acknowledge the necessity of what McKerrow (1989) calls the "critique of domination," the critique of those with powerful vested interests. In this essay, however, we explore the critique of vernacular discourse in order to confront disquieting elements of poststructural theory as it has been practiced - the concentration on the generalized, transhistorical, transpolitical subject and the avoidance of discussions of people struggling to survive. ${ }^{5}$ As Baker (1989) notes, all too often poststructural theory has implied "an ideological and sometimes willed blindness to any version of the past that suggests real events, actual human bodies, or a responsibility to such phenom- 
ena" (p. 88). That is, Baker notes that, discursive or not, Frederick Douglass still suffered the "stripes on my back, inflicted by your direction" (p. 99). The focus of much recent work has not been on subjects but on how subjects are formed. In decentering the subject, "lived pain" is too often forgotten. We argue that a critique of vernacular discourse is necessary to render power relations among subjects visible; this approach, we believe, will allow critics to move beyond challenge to transformation. ${ }^{6}$

\section{CHARACTERIZING THE VERNAGULAR}

By defining vernacular as we do, we argue that while it is necessary to make vernacular discourse and the power relations it constructs visible, it is not enough just to recuperate, locate, and catalogue vernacular discourse. For example, if we were to examine a variety of vernacular discourses, we could not stop by saying that rap music exists, that discourse by Frederick Douglass exists, or that pidgin English exists. We would only be describing what we find, and in the process of description, we would be translating such discourse nonreflectively, without acknowledging our intentions, our biases, and our purposes. Recuperative/descriptive studies of vernacular discourse tend to be anthologies or compendia of documents, usually discovered by rhetorical historians in order to be seen appreciatively by new audiences. Uncovering vernacular discourse is a worthwhile goal, but a more important goal is to construct a critical framework within which to discuss vernacular discourse; uncovering vernacular discourse is not, by itself, a liberatory practice. ${ }^{7}$ Finding and describing vernacular discourse will not simply, by virtue of the discourse being vernacular, represent a positive political, cultural, and social agenda. In order for discourse to become practical, we must move to a new level, that of critical suspicion, the kind of suspicion that rhetoricians have always given mainstream discourse. Otherwise, analysis of discourses not already being studied remains a practice presupposed by current frameworks, the very frameworks that have allowed for historical studies that do not address vernacular discourse.

We argue that vernacular discourse, such as African American cultural theory that theorizes the specific experiences of African Americans, ${ }^{8}$ needs to be criticized. Unless critical attention is given to vernacular discourse, no new concepts of how community relations are interwoven and how communities are contingent is possible. Without a critical framework, description occurs without self-reflection; hence, ideological presuppositions unconsciously may be reproduced. To begin constructing a critical apparatus wherein vernacular discourse can be examined, we describe two characteristics of vernacular discourse below: its cultural syncretism and its function as pastiche. A focus on these two characteristics allows us to move beyond pure description and cooptation of vernacular culture and to engage in active political change.

\section{Cultural Syncretism}

In describing the historical and political specificity of African American culture, Todd Boyd (1991a) suggests that African Americans are not so much acculturated into mainstream society as they are involved in a cultural syncretism that affirms various cultural expressions while at the same time protests against the dominant cultural ideology (p. 101). Boyd's model is relevant to the study of 
Japanese American discourse because it allows us to see how a critical framework can be developed that responds specifically to the marginal position of African Americans. ${ }^{9}$ The notion that rhetoric affirms as it protests is not new within rhetorical criticism. In Kenneth Burke's (1966) proposition that humans are defined by the negative, there is the sense that every affirmation is simultaneously a negation (pp. 9, 419-420,457, 461, 472). ${ }^{10}$ What sets Boyd apart from Burke and others is his emphasis on the culturally specific discourse of African Americans and on how affirming an African American subjectivity and protesting Hollywood representations of African Americans go hand in hand. Boyd stresses the idea that marginal communities negate in unique ways. For Boyd, vernacular discourse "challenges the dominant white discourse on blacks in American society" (p. 100). It does this by producing culturally specific rhetoric within African American communities.

Different from Gregg's (1971) argument that the "ego-function" of African American "black power" rhetoric is self affirmation, Boyd (1991a, 1991b) emphasizes social and cultural aspects of discourse, not psychological ones. For Boyd, vernacular discourse constitutes African American communities, constructs social relations, and protests representations of African Americans circulating in dominant culture. The major point here is that through criticism of culture produced within African American cultures, constructions of African American subjectivities are created in the process, constructions that confront dominant images of African Americans. While Gregg argues that the primary effect of the rhetoric of "black power" was oriented toward enhancing an individual revolutionary's ego, Boyd sees African American rhetoric as protesting images of African Americans within mainstream discourse in ways that improve the lives of African Americans as a whole. In his view, culture and protest are interwoven elements of vernacular discourse.

While focusing on the cultural and social aspects of African American discourse, Boyd also begins to explain how critics should approach the study of African American film. Boyd calls for theorists to create a critical apparatus, envisioned within African American culture, through which critics can begin to analyze culture without the "master's tools." "l Critics should begin by locating and situating African American culture within a historical and cultural context that explains how African American representations came to be (Boyd, 1991b). Then, critics should conduct a critical analysis of vernacular discourse. ${ }^{12}$

What must be stressed about Boyd's (1991a, 1991b) theory is that vernacular discourse does not exist only as counter-hegemonic, ${ }^{13}$ but also as affirmative, articulating a sense of community that does not function solely as oppositional to dominant ideologies. By expanding Boyd's theory to include other counterhegemonic discourses, we can develop Boyd's theoretical notions further. For instance, if we were to expand the theory of the vernacular into the examination of discourse constructing homosexuals, we might begin to realize that all homosexual communities are not constituted solely in opposition to homophobia (although this is one concern and hence one way in which homosexuality has been constituted). We might learn that homosexuals are constituted as affirmers of lesbian and gay rights, as critics of governmental AIDS discourse, as supporters/critics of lesbians and gays in the military, and in multiple other ways that cannot be known or guessed at when one is not educated within the vernacular. 
Another example of how the critique of vernacular discourse might function is to analyze contemporary rap music. Rap does not always self-reflectively (through albums or videos) articulate hip-hop or African American communities as oppositional to the dominant ideology. Chuck D of Public Enemy has noted on several occasions that rap serves as the "CNN" of the African American community, providing a national news outlet for how African Americans are viewing specific cultural events, such as the beating of Rodney King, the trials of the police officers who beat him, and the aftermath (Owen, 1990, p. 57). Rap is not necessarily self-consciously counter-hegemonic, though its effect may be a rearticulation of hegemonic relations. Even when it does not self-consciously do so, however, it may implicitly counter the dominant ideology. More importantly, rap enacts a forum for the expression of cultural mythology.

So far, we have shown how vernacular discourse is culturally syncretic (i.e., culturally affirming, not primarily counter-hegemonic). We have also shown how the critique of vernacular discourse might broaden its scope so as to understand subjectivities in many locations. Below, we will broaden further the critical apparatus Boyd envisions by suggesting that vernacular discourse is constructed out of fragments of popular culture. Thus, we argue that vernacular discourse forms a pastiche of popular culture from elements that have been torn out of context for the explicit purpose of constituting new effects.

\section{Pastiche}

Pastiche implies that vernacular discourse may borrow from, without mimicking, popular culture. As Baker (1984) writes, "The vernacular (in its expressive adequacy and adept critical facility) always absorbs 'classical' elements of American life and art" (p. 12). Hence, vernacular discourse is constantly engaged in the process of pastiche, in constructing a unique discursive form out of cultural fragments. Pastiche fractures culture in the process of appropriating it through imaginative reconstructive surgery. For example, rap music uses the technologies of sampling and scratching in the production of albums. Sampling usually means to take music that has been played on "top 40" stations and edit bits of it into the rap. An example of this is Luther Campbell's rap revision of Bruce Springsteen's song, "Born in the U.S.A." More politically conscious rap tends to sample early rappers such as Kurtis Blow, Grand Master Flash and the Furious Five, H. Rap Brown, Spoonie G, and The Sugar Hill Gang. Scratching, ${ }^{14}$ which has become more and more technologically sophisticated, both effaces the original and creates a whole new sound.

In these examples, pastiche refers to a processual and active practice, not as Jameson (1992) argues, the "imitation of a peculiar or unique, idiosyncratic style" (p. 17). For Jameson, pastiche is "mimicry," though a more sober mimicry than parody. It is immobile, fixed, and lifeless. However, as we define it, pastiche is an embodied practice that is everchanging, active, and constantly motivated by a concern for local conditions and social problems. ${ }^{15}$ When borrowing from popular culture, vernacular discourse emphasizes invention and organization and reconstitutes discourses within specific racial, cultural, gendered, and ethnic communities. Vernacular discourse can combine elements of popular culture in such a way as to create a unique form that implicitly and often explicitly challenges mainstream discourse, while at the same time 
affirming and creating the community and culture that produce vernacular discourse.

McGee's (1990) understanding of postmodern culture can be seen as a metaphorical description of how pastiche is constructed. McGee notes that "rhetors make discourses from scraps and pieces of evidence. Critical rhetoric does not begin with a finished text in need of interpretation; rather, texts are understood to be larger than the apparently finished discourse that presents itself as transparent" (p. 279). Because hegemonic discourses are pervasive, so pervasive that the hegemonic constructions of marginalized members of society are created through public media, members of vernacular communities often use fragments or "scraps" from hegemonic discourse to construct subjectivities. While McGee is prescribing how critics should criticize in postmodern culture, we are using his model to describe how vernacular discourses function naturally through pastiche. Thus, critical rhetoricians would begin to see how rhetors within specific cultural settings create a culture-specific language through which to communicate within those communities.

A very clear and self-reflective demonstration of the reconstruction of fragments rearticulated through the vernacular can be found in jazz and the recent reworkings of its tradition by trumpet virtuoso and theorist Wynton Marsalis (1986). ${ }^{16}$ In a discussion of the place of jazz in relation to African American identity, Marsalis notes that early jazz musicians would take show tunes, as composed by George Gershwin, for example, and rework them "through the Negro methodology of swing" (p. 131). In a discussion of the music of Charlie Parker, Marsalis notes the way in which Parker drew upon elements of popular culture and high art but made music that was clearly located and articulated through his lived experience as an African American: "There is nothing European-or even African-in Charlie Parker's music in the sense that it can be reduced by comparison to an external source. I say that because the term Black American means a synthesis and a fresh expression of all elements anyway" ( $p$. 134). Jazz music, then, is a pastiche that in Marsalis' mind could only have been articulated through a creative combination of cultural artifacts. The pastiche in rap music is not unlike pastiche found in jazz music. In rap music, we see the widespread growth of vernacular expressions, not only in African American, but in Latina/Latino, Asian, and Asian American cultures. Additionally, rap music draws upon rock (e.g., Ice T) or the current reworkings of jazz (e.g., Diggable Planets). In each case, a community is constructed out of elements of culture, a vernacular community that is primarily affirmative, implicitly counterhegemonic, and heuristically worthy of critical contemplation.

This is not to say that pastiche has to be constructed by bringing together hegemonic culture in all cases. There is, within a polyglot culture such as Hawaii, for example, the possibility of bringing together multiple cultures (e.g., Japanese, Puerto Rican, and Samoan) to create a specific cultural expression, reserved for the working class. Pidgin, which has been referred to pejoratively as a "broken" language, cannot be understood by the hegemonic culture and therefore functions syncretically, to affirm and protest, through a pastiche of other languages. Additionally, the combination of rap music with reggae constructs an art form that, when uttered at high speeds, is virtually incomprehensible to the majority of listeners. Thus, pastiche need not be a construction of various forms of hegemonic culture only, but may in fact draw from specifically 
marginal discourses for specific audiences well-versed enough in the vernacular to understand the messages.

While cultural syncretism and pastiche allow us to define vernacular discourse, we are not suggesting that analysis of vernacular discourse necessarily leads to "positive" representations. Theoretical discussions have the tendency to understand cultural syncretism and pastiche as necessarily constructing "better" realities for nondominant groups. This tendency in literature is perhaps clearest in Trinh's (1989) discussion of the vernacular, an ironic discussion where the virtuous "vernacular" is contrasted against the "pure," "unambiguous," "logical," "unparadoxical" "vehicle of thought"-rhetoric. She writes, "Vernacular speech ... is not acquired through institutions-schools, churches, professions, etc. - and therefore [is] not repressed by either grammatical rules, technical terms, or key words" (p. 16). For Trinh (1989), vernacular speech (she is distinguishing between spoken and written words) is an

abstract-concrete, personal-political realm of excess not fully contained by writing's unifying structural forces. Its physicality (vocality, tactility, touch, resonance), or edging and margin, exceeds the rationalized "clarity" of communicative structures and cannot be fully explained by any analysis. (p. 44)

For her, "writing the body," a form of vernacular discourse that cannot be contained within rhetorical analysis, constitutes itself by articulating itself as such.

However, we shall suggest by applying our theorization of vernacular to Japanese American discourse in The Pacific Citizen during World War II that idealized versions of vernacular discourse necessarily fail to address the multiplicitous layers within which vernacular discourse operates. Not only do vernacular discourses fail to create positive representations simply through their utterance, but rhetoric itself may be the means by which a more fully articulated cultural space can be created. Rhetoric may be the defining way in which representations of Japanese Americans come to create idealized subjects. As we shall see, and this becomes an extension of the theoretical paradigm we have presented, vernacular discourse does not, by definition, enable constituents of vernacular cultures to articulate liberatory political identities and subject positions. Critical rhetoric allows us to see exactly how such positions may in fact work against the political project to discover enabling subjectivities. Just as rap, jazz, and black power may not always construct positive representations of culture, Japanese American discourse may not construct positive representations in every instance. As a result of this last caution, we note that the practice of the criticism of vernacular discourse should have as its goal a critical framework that works to upend essentialisms, undermine stereotypes, and eliminate narrow representations of culture. Criticism that essentializes or "reifies" (stabilizes signification within a system of discourse so that it becomes difficult to dislodge and becomes rigidified) should be displaced and altered in order to avoid further marginalization of vernacular communities and to allow for a critical reading of the effects of vernacular discourse.

\section{CRITICISM AND DISPLACEMENT}

The critique of vernacular discourse necessarily entails combining a critical approach to discourse (e.g., the "critical rhetoric" orientation) with an emphasis on continuous discursive displacement. By displacement, we mean that the 
rhetorician takes a critical view of the construction of essentialism and reification. A critique of vernacular discourse strives to understand how a community is constructed and how that constructed community functions. By looking at the complex operations of cultural syncretism and pastiche, the critique of vernacular discourse attempts to illustrate other possible realities, not to articulate a vernacular "space" for further marginalization. Yet, marginalization is still an everpresent risk of such a practice. Caution can be taken by respecting the ways in which communities, including marginal ones, are always "in transition," never fixed, never essentializable. The examination and analysis of vernacular discourse we advocate upends essentialist moments and diminishes the stability of every subjectivity. That is, a critique of vernacular discourse disallows hegemonic constructs of marginalized communities by revealing the ways in which vernacular discourses are always in process. While essentialism inevitably occurs as a process of discourse, we argue for a conditional essentialism for the moment, an essentialism that is eternally displaceable. Such essentialism may be used by counter-hegemonic groups in order to construct strategic representations, even though the stability of such essentialisms must always be disrupted.

One danger of defining a unifying vernacular discourse that does not acknowledge and adapt to the changing aspects of culture is to entrench and rigidify discourse into the social role of the "marginal." While Trinh maintains a narrow view of rhetoric, her understanding of displacement is far more eye-opening. As Trinh (1991) notes:

The margins, our sites of survival, become our fighting grounds and their site for pilgrimage. Thus, while we turn around and reclaim them as our exclusive territory, they happily approve, for the divisions between margin and center should be persevered, and as clearly demarcated as possible, if the two positions are to remain intact in their power relations. (p. 17)

By focusing on vernacular discourse, then, we necessarily run the risk of creating a nonadaptive marginal discourse only able to function in tandem with the dominant. As critics, we must be careful that our criticism of vernacular discourses does not create understandings of vernacular cultures as unchangeable or simply as margins in opposition to a fixed and rigid center. Not only, then, as Trinh points out, should members of marginal communities not be objectified for the benefit of hegemonic culture, but critics should work to prevent such essentialisms from operating to create dialectical power relationships of margin/center.

In recognizing that vernacular communities, like all communities, are in a state of persistent transition, we, as critics, attempt to prohibit our tools of classification from becoming so powerful that our criticism of vernacular discourses creates objectified communities (Trinh, 1991, p. 17). As Trinh (1991) argues:

Displacing is a way of surviving. It is an impossible, truthful story of living in-between regimens of truth. The responsibility involved in this mostly in-between living is a highly creative one: the displacer proceeds by unceasingly introducing difference into repetition. By questioning over and over again what is taken for granted as self-evident, by reminding oneself and the others of the unchangeability of change itself. Disturbing thereby one's own thinking habits, dissipating what has become familiar and cliche'd, and participating in the changing of received values-the transformation (with/out master) of other selves through one's self. (p. 21) 
What Trinh describes here we see as that "in-between" space where vernacular discourse borrows material from cultures to create a vernacular one-a "highly creative" pastiche. ${ }^{17}$ Such a pastiche constantly upends repetition and reconstitutes the epistemological grounds on which a vernacular discourse is founded, forever altering relations of power that function via stability of discourse.

In sum, a critique of vernacular discourse recognizes that communities on the margins, while sometimes constructed from dominant cultural discourse and while constituted to some degree as counter to the dominant ideology, are also affirmative, hence syncretic, constructing identities that function within vernacular communities and can be effective there. As rhetors engaged in a critique of vernacular discourse, when we study the ways in which marginal communities are constituted, we show the ultimate respect not by attempting to allow space for a "reified" margin to speak within the hegemonic culture, ${ }^{18}$ but by recognizing the transitional nature of marginal communities and the ways in which such communities may purposefully construct themselves outside of hegemonic culture. It is in this spirit that we exemplify the critique of vernacular discourse in a reading of the construction of Japanese Americans in a Japanese American newspaper during World War II.

\section{CONSTRUCTIONS OF JAPANESE AMERICAN WOMEN IN THE PACIFIC CITIZEN}

Our analysis of the construction of Japanese American women in the Pacific Citizen during World War II will illustrate how a critique of vernacular discourse works both to recognize the oppositional and affirming qualities of the discourse and to recognize ways in which that discourse functions to construct power relations through representations of Japanese Americans. Similar to analysis of rap music, jazz, and pidgin, the critique of vernacular discourse here will work to identify pastiche, syncretism, and to upend essentialism through an analysis of a Japanese American newspaper. The historical differences between, say, rap and the Pacific Citizen are important at one level, and for our argument the historical and cultural differences highlight just how important it is to specify the cultural space being contextualized.

The time period chosen is appropriate to the case we analyze because during World War II more than 112,000 Japanese Americans on the West Coast were arrested and incarcerated in concentration camps throughout the western and midwestern United States. This time period has historical relevance because the constructions of Japanese Americans during WWII has had strong influence on how Japanese Americans are seen today. We examine historical relations in order to re-"orient" discussions toward local cultural communities, much as we would if we were to examine carefully contemporary constructions of African Americans in rap music. We focus specifically on the construction of women in the Pacific Citizen during World War II (1942-45) as a site of contestation over the definition of Japanese American communities at the time of extreme crisis and confrontation within hegemonic culture. We choose to focus on women because their specific location within Pacific Citizen discourse is constituted as ideal for Japanese American subjects.

The reasons for choosing this artifact are legion. The Pacific Citizen is a vernacular newspaper widely circulated among Japanese Americans during war 
time and has persisted as an emblem of a voice of Japanese Americans into the present. The Pacific Citizen was published in Salt Lake City, Utah, and its editorial staff, for the most part, ran the newspaper in Salt Lake City. Because Japanese Americans were evacuated from the West Coast, some Japanese Americans who lived inland were not imprisoned. This newspaper, written and published by Japanese Americans, explicitly claimed to speak on behalf of Japanese American people during World War II. By professing to speak on behalf of Japanese Americans, it also created a specific relationship of power to the U.S. government and to Japanese Americans who resisted and protested the oppression of incarceration, exemplifying syncretism and pastiche. Censorship did affect the newspaper production during the time period, but in the specific case of the Pacific Citizen, self-censorship may have been enough to prevent heavy-handed government intervention (Omura, 1989). Regardless of censorship, however, this paper was founded by, run by, and directed to Japanese Americans. The Pacific Citizen, even while it sometimes did address a mainstream U.S. audience, directed its messages primarily to Japanese Americans in concentration camps. Moreover, Japanese Americans have since defended what they said in the Pacific Citizen during wartime. ${ }^{19} \mathrm{We}$ do not conduct an analysis of audience, and we do not conduct a media history. Rather, we examine discourse within the Pacific Citizen to show how the newspaper constructs itself as a vernacular medium through which information about Japanese Americans is articulated.

Our choice of the Pacific Citizen reveals a preference for discourse that addressed a Japanese American audience during the War. In accordance with our definition of vernacular discourse, we could have examined autobiographies of Japanese American women, ${ }^{20}$ camp newspapers, leaflets written by prisoners within camps, or contemporary films by Japanese Americans depicting concentration camp life; or we could have conducted an ethnographic study of Japanese Americans still alive. ${ }^{21}$ We chose the Pacific Citizen, however, not only because Japanese Americans during wartime read the newspaper, but also because the Pacific Citizen is the largest transhistorical Japanese American newspaper, written in English, to have preceded and followed the war period. This kind of continuity allows us to show how the ideal Japanese American subject is constructed during a particular moment in history.

We will argue that the newspaper, while self-consciously establishing a discursive relationship with government, constructed relations through representations that highlighted their passivity and that the Japanese American woman was the emblem through which the Pacific Citizen created stereotypically passive subjects. ${ }^{22}$ In other words, the Pacific Citizen advocated just that-a pacific citizen - who could be molded and shaped to fit an ideology of U.S. military violence. This example shows how important it is to maintain a critical perspective that recognizes vernacular discourse is not, by definition, liberatory.

The focus on the construction of women takes race and gender as operative aspects of the construction of subjectivity within the newspaper and suggests that by recognizing these two cultural aspects in our analysis, a more critical approach to vernacular discourse can be accomplished. By focusing on the construction of women within the newspaper, we are suggesting that analysis of vernacular discourse must have the critical capacity to undertake questions of 
multiple moments of marginality-gender and race. Such a focus supports our suggestion that the critique of vernacular discourse be made always in order to upend and displace fixed representations.

We focus on three depictions of Japanese American women in the Pacific Citizen during this time period, each of which constructs a passive subjectivity. The first representation focuses on the War. While newspaper stories recognize women's suffering, mental anguish, and despair as resulting from confinement, isolation, and pain, stories nonetheless focus their attention on boosting morale toward the war effort. Women are encouraged to support men and their families-to pull themselves together for others. A second representation valorizes letter-writing as a specific form of resistance women should take. In combination with images of Japanese American women as obedient and dutiful family workers, the paper encourages women to write letters to Congress as a means of voicing their disenchantments, which were many. A third representation focuses on women's duties. While early stories concern themselves with what women wear, how they look, and how they decorate their homes, later stories argue that women have the further duties of teaching, typing, and perfecting secretarial skills as a means of gaining employment when released from prison. After discussing these representations, we will then analyze and examine them. Finally, we will discuss the relationship of the critique of Japanese American women to the critique of vernacular discourse as a whole.

\section{War Morale}

Stories attempting to boost women's morale worked in tandem with stories about women's depression and despondency caused by the war. A July 23, 1942, story, titled "Despondency Over Evacuation Drives Woman to Suicide," alters the prevailing argument within the Pacific Citizen that women were passive and obedient subjects while confirming the fact that prison camp life was experienced as unsurvivable. A Selma, California, woman, "Mrs. F. Nogawa, 55, . . was said to have been found dead in the garage of her home by members of her family." Her family apparently "told Deputy Coroner Luther Byrne that she had been despondent for some time over the impending evacuation of Japanese from the area" (p. 8). While the article ostensibly shows how depressed women became, it might also suggest that suicide could function as a rhetorical response to oppression.

Because despondency is discussed regularly, Ann Nisei's column, a regular column discussing women's issues in accordance with the overall tenor of the newspaper's content during wartime, does not ignore the mental strain women might suffer. ${ }^{23}$ Ann Nisei (1943) tells readers in the article "Question of the Hour: Shall I Leave the Center?" that suffering in prison is more rational than escaping from prison. She writes, "When some unpleasant incident does happen to you, don't let it get you down. Most incidents can be laughed off, if you keep your sanity and keep your sense of humor... . You've a bigger job to do right now than worry. You've a home to build, a living to make, a family to take care of" (p. 6). Ann Nisei encourages women to replace their worries about "unpleasant incidents" that might make them want to leave with other worries about building a home, making money, and taking care of their families. While this might be seen as an encouragement to women to use their energies 
productively rather than channelling energies into unproductive behavior, Ann Nisei nonetheless encourages greater responsibilities for women, responsibilities that translate into stereotypically gendered behaviors. Ironically, these added responsibilities, even if productive, occlude productive activities such as political action and involvement in protest. Moreover, they invite women to think about added responsibilities, as if their responsibilities and worries were not already enough. Nisei suggests more responsibilities and more worries will provide relief from other worries.

In contrast to depictions of women's despondency and depression, other articles focus on women's attempts to boost morale of military men, sometimes through their own physical visibility. One article goes so far as to show how images of women as "pin-up girls" could be used to boost morale for enlisted servicemen. The article, entitled "Story of the Week: Nisei Girl is "Pin-Up Queen' of U.S. Forces in Pacific" (1943), tells the story of "Miss Tsuyama," who is described as " 18 and little." The story, a synopsis of a United Press International (UPI) story by Richard W. Johnston, describes not only her modeling duties as "pin-up queen," but also the expectation that she will hug and have her picture taken with any GI who pays $\$ 1.25$ "because a girl in the arms is worth two pictures of Betty Grable in the barracks" (p. 3). The article summarizes: "A little 18-year-old Japanese American girl is one of the three reigning "pin-up queens of the Pacific,' among America's soldiers, sailors and marines stationed in the Hawaiian islands" (p. 3).

Early in the war, an article declaring "Victory Resolutions" for women ran in the Pacific Citizen ("Victory Resolutions," 1942). These new year "resolutions" essentially were rules of conduct for women during wartime. They call for women to "volunteer [their] services," "co-operate wholeheartedly," donate "waste-paper, aluminum, etc.," show "tolerance by harboring no prejudices against aliens," and buy U.S. savings bonds, but not to "spread uneasiness or panic" or hoard "excess purchases." To "co-operate wholeheartedly," women should prepare their homes and families "for any emergency" (p. 7). Essentially, the victory resolutions encouraged women to keep quiet and give all they could to their country. In addition, the resolutions encouraged European American women not to hold prejudices against "alien" Japanese American women. Thus, this article served the dual purpose of encouraging both Japanese American and European American women to support the war by purchasing goods and to suppress their self-perceived racism.

Women are often encouraged to show support for the war through domestic labor. In her June 4, 1942 column, Ann Nisei explains how women in "reception and assembly centers" realize that they have to adjust to different domestic roles in order to maintain their efficiency at domestic duties. She says, "The young Nisei mother no longer plans three meals a day. She and her family eat in a mess hall, the meals planned and cooked by others. She has no backyard to tend, no private home to clean" (p. 5). She writes further, "But each camp will need hobby classes, libraries, adult education and all the other things necessary for a rounded life." The women in "camp" must "remember that adults as well as children need to hav[e] their time occupied. Boredom in camp will breed brooding, and brooding breeds despair. And we cannot allow despair to rule our children, our parents, or ourselves" (p. 5). While women are freed from 
their traditional domestic duties, Ann Nisei naturalizes the need to develop alternative duties by representing them as solutions to despondency and support for their warring country.

Ann Nisei counsels women in prison to channel their energies in "positive" ways. In another article that month, Ann Nisei (1942 June 25) historicizes and in so doing defines women's existence within the prisons by saying women work in the centers as nurses, secretaries, librarians, teachers and social service workers. They have organized schools, libraries, nurseries, classes, and recreational activities. They run milk canteens and typewriters. They write for camp newspapers and teach knitting (p. 5). Here, as elsewhere, Ann Nisei and the Pacific Citizen represent women as supporters of the community, in addition to supporters of their families and supporters of military men.

\section{Writing As Resistance}

In addition to offering the contradictory depiction of women's despondence and of women as supporters of the family, community, and war, the Pacific Citizen constructs another contradictory representation of women as being both obedient and resistant. In a story about the Poston resistance in November 1942, women are brought in toward the end of the article as examples of the innocent people harmed by disorganized and misdirected rebellion within the camps. The article describes the actions of "the agitators" and then goes on to show how those actions harmed women and children. It reads, "Effectiveness of the agitators in getting workers to quit their jobs, officers said, was due largely to the fact that most of the workers were youths and women who were frightened by threats" ("Five-Day Disturbance," 1942, p. 1). Shortly after this remark, the article suggests that the agitation was successful because it was able to demonstrate the ineffectiveness of Japanese American Citizens League ( JACL) leadership.

In a similar article about the Tule Lake concentration camp during civil disobedience by nearly 6,000 unarmed men nearly a year later, the depiction of women exemplifies, contrary to the actions of the "rebellious" male prisoners, how loyal citizens should act ("Troops Impose Martial Law," 1943). The article details the agency of military troops controlling the "disloyal evacuees" and inaccurately reports that deceptively peaceful protestors beat a guard without provocation. ${ }^{24}$ Toward the conclusion of the story, the article reads, "Although the women do not work in the harvest fields normally, they continued work uninterrupted at other tasks" (p. 7). The article argues that men protested by not working in the fields and "patriotic" women and children kept themselves preoccupied with "other tasks." The gender divisions are magnified through the text by suggesting that even when men do not do physical labor, women, because they are women, cannot replace them. Certain tasks (e.g., physical labor) require a certain gender.

Both in response to a perceived lack of involvement of women in demonstrations and in response to depictions of women as despondent, articles by Oyama (1943) suggest, among other things, that women should write letters, an activity that is a staple depiction of women's resistance within the newspaper. Oyama takes women and women's lives seriously. She acknowledges the mental, physical, and emotional trials of prisoners. She writes, "It took Nisei of exceptionally 
well-integrated character to survive the vitiating ordeal of months of restricted confinement" (p. 6). She argues that only Christians or "unconfused liberals" could survive the incarceration, though she says many Japanese Americans are neither. She continues by saying that "the vast majority of the Nisei were utterly lost in a mire of deepest confusion-psychologically, spiritually, intellectually" (p. 6). In an attempt to show what can be done to survive the harsh realities of prison life, Oyama then gives suggestions of what Nisei should do, such as go to church, join nonsegregated social organizations, become members of the JACL, write letters, and show loyalty (p. 6). Of all of these suggestions, letter writing is the only resistant act in which a woman can take part that does not highlight her femininity through supportiveness.

Similar to the articles that encourage women to take care of domestic duties and to be loyal citizens, many articles about letter writing focus on women's duty to support the war. In the article "In Defense of Cause of Nisei" (1942), Charlotte D. Susu-Mago is said to have written a "letter of protest" to Congressman Leland Ford, who advocated the incarceration of all Japanese Americans. In her letter, quoted in paragraph-length passages, Susu-Mago compares Japanese Americans with Italian Americans and German Americans, arguing for fairness in the treatment of Japanese Americans. Then she goes on to argue that Japanese Americans "are buying defense bonds far out [of] proportion both to their numerical strength and the state of their finances" since Pearl Harbor (p. 4). She says Issei have been fired, their shops have been closed, and their money has been kept from them. "The younger generation upon whom the burden for the support of their parents and families has suddenly been thrust, have also in many cases been cut off from work" (p. 4). In spite of this, Susu-Mago argues that Nisei outnumber their Caucasian counterparts in the enlistment in the army by a ratio of two-to-one. "And, also in spite of discrimination, persecution, threats, insults, loss of position and concern for parents, many of whom have been interned already, the Nisei are still better Americans than some who were born with white skins" (p. 4). Susu-Mago's letter of protest modestly asks for "fairness" in treatment, while the rest of her argument suggests that Japanese Americans have done more than their fair share to support their country during wartime.

Susu-Mago's letter does not discuss the conditions of imprisonment, but one letter, written by an unnamed "Nisei girl," explains the conditions of imprisonment in an Idaho jail ("Nisei Girl Writes," 1942). She writes, "Some of the townspeople are up in arms for our coming, and are threatening mob violence so that is the reason why we are in jail" (p. 5). She goes on to describe the unsanitary conditions, the bad food, the threat of violence, and she says she is getting a cold (p. 5). While this letter describes deleterious aspects of prison life, the letter itself constructs women as helpless to do anything about it. This letter also reasons that Japanese Americans are in prison for their own safety, a significant argument government used to justify the incarceration of Japanese Americans during the period.

\section{Women into the Workforce}

Early representations of women in the Pacific Citizen focus on women's dress, make-up, and fashion. In her editorial, Ann Nisei (June 4, 1942) writes, "[the 
Nisei woman] had the average American woman's interest in a good recipe, a new decorating idea, a striking new fashion. She read avidly about the new length in skirts, and she tried to be up-to-the-minute on home and beauty care" (p. 5). Another article ("Nisei Woman," 1942) describes ways women can make use of worn clothing without sacrificing fashion. The article concludes with, "Fabrics used in last year's clothes may give as good wear as new cloth bought later on. Don't waste it" (p. 5). In these examples, women "work" on themselves and their clothes. Unable to buy new clothes, they are to use what they have creatively.

Later representations shift the focus from women's fashion consciousness to education by encouraging women to move quickly from respectable educational institutions into significant jobs in the workforce. In an article "Nisei Girls Take Jobs in Milwaukee" (1943), Mari Okazaki, 27 (a graduate of the University of California) and Emi Okazaki (a graduate of a junior college) are described as "two pretty Nisei sisters" who "were transplanted" to Milwaukee by the War Relocation Authority (WRA) from the Manzanar concentration camp in California "as the first of a group of American Japanese who are to be resettled in the Milwaukee area from WRA centers" (p. 2). The move from college to jobs with the International Institute (Mari) and a physician's office (Emi) represents the possibilities for achievement by Japanese Americans, nearly two thirds of whom remained imprisoned until the end of the war. The article gives no details to show how women felt about leaving prison and about leaving their families at Manzanar. But a detail that "they were happy that a younger sister, Yuriko, 18, is to be permitted to attend college" is included, along with the information that the rest of the family hopes to be released soon (p. 2).

A similar article that discusses the post-prison employment of Japanese Americans, titled "Resettlement Program Affords Opportunity for Nisei Women to Apply Specialized Talents" (1943), highlights women's work success. Adapted from an article by Jack Steele in the New York Herald Tribune, the article discusses the employment opportunities in Chicago given to "evacuees." It says, "The great majority of evacuees, both men and women, are now well accepted, well adjusted to their new environment and expect to stay in the Middle West after the war" (p. 18). According to the article, women were the first to leave the prisons to go to work in nondomestic jobs. Though there had been two protests, there were now 2,000 Japanese Americans "resettled" in Chicago, compared to the 300 Japanese Americans living there before the war. Accompanying the article is a photograph of a Japanese American woman typing. The caption under the picture reads, "one of the thousands of Japanese American women who have left relocation camps in the past year and are applying their specialized training to help fill the nation's manpower needs" (p. 18).

Another article focuses solely on upward mobility of a "Nisei girl" into the military. In the article, "First Nisei Girl Accepted for Service in WAAC [Women's Army Auxiliary Corps]" Mary Arakawa, 21, is said to be reporting for basic training after enlisting in the Army in Casper, Wyoming (1943, p. 1). Arakawa, who "hopes to pursue her nursing career in the army" overseas, is said to have waited a long time before being accepted as an enlistee (p. 1). In another article demonstrating Nisei women's upward mobility within the workforce, "girls" are "trained to work in fire departments as secretaries and stenographers" ("Fire 
College," 1943, p. 1), not to fight fires themselves; but the move from domestic to clerical labor is a shift in women's work and women's lives that alters their social and economic position within society.

\section{DISCUSSION}

The example and examination we give here are brief. We hope to exemplify aspects of vernacular discourse that we have theorized and draw conclusions about the critique of vernacular discourse. Throughout these representations of women within the Pacific Citizen (1942-1945), what becomes clear is that women are not represented as a unified set of individual human beings, nor are they constructed in one specific way. In fact, because the representations are so varied and often contradictory, the importance of their constructedness is not at all in their coherence but rather in their existence in an array of multiple discursive moments: mothers, daughters, workers, objects, resisters, students, supporters, and clothesmakers. Trinh $(1989)^{25}$ and Butler (1990) both have argued that disunified and multiplied subject positions created through difference offer potential sites for liberation. Trinh and Butler's theoretical positions are important because they suggest an alternative to the modern and traditional view of a unified subjectivity. Multiple discursive moments, however, do not, in and of themselves, avail subjects a liberatory position and in fact may work textually to construct a rhetorical apparatus that reconstitutes woman within an oppressive ideology; even if the vernacular is concerned with local conditions, these concerns can at times be more hegemonic than not. While women are shown protesting, which may be a positive political achievement during the time period, this protest is limited to writing letters, not to changing their identities or establishing women's organizations that would function to change relations between women and men. Similarly, while the Pacific Citizen acknowledges women's despondency, it counters it simply with advice on building morale.

Through a contradictory construction of women's mental suffering and their support of war morale, the encouragement of nonresistance and the valorization of letter writing as a means of resistance, and through the depiction of women as malleable bodies and good workers, the Pacific Citizen effects an idealized version of women's subjectivity. In the Pacific Citizen, women's subjectivity is always in a state of transition to a fuller, more satisfactory, yet unfinished, form. An ideal body type, an ideal emotional state, and an ideal economic and political role are constructed as tonics for despondency and racist oppression. Women are constructed as models of ideology, and their images are always being reconstructed. This representation of women as idealized "pacific citizens" may register as a positive, and affirmative, construction for Japanese American and offers one possible resistance against the society imprisoning them. Thus, it is culturally syncretic. However, this representation functions to construct this image so as to limit the political potential of Japanese American women's resistance.

In order to assimilate into the overall ideology of the country during wartime, the Pacific Citizen often asks women to exaggerate their appearances to make themselves look more appealing to men. Women are infantilized in the Pacific Citizen, as is exemplified in the descriptions of "Miss Tsuyama" as "little." The article also leaves out her given name and hence objectifies Tsuyama as a 
nameless face, unmarried and available. Her namelessness has two dangerous effects: It fosters the sexualization of her as an object of men's desire, thus as a woman without a purpose other than to be viewed and bought for sexual pleasure; and it encourages her objectification as a Japanese American woman, as sacrificial and inhuman. The article makes it clear that Tsuyama's role as a "pin-up queen" helps to support the war effort, ${ }^{26}$ thereby supporting U.S. military (masculine) dominance and the system of power relations that necessitates women's sexualization and objectification in order to construct a successful campaign of mass violence against other people. What is significant about this is that the construction of women within the Pacific Citizen constructs a racial and gendered subjectivity for women, one that in both cases is ideologically numbing.

The newspaper's use of articles both from mainstream publications and from other Japanese American newspapers is a staple method for filling print space. In the examples above, what we might call "adaptation stories," stories are printed in other newspapers first and then are reprinted in the Pacific Citizen as fragments. Originally, the story of "Miss Tsuyama" was a UPI story, and the story by Jack Steele was a New York Herald Tribune story. Some stories are not explicitly "adaptation" stories, such as the article on war bonds; but because of the generic nature of the story, they do not appear to be specifically addressed to a Japanese American audience, most of whom are imprisoned and have little money. The story of the Nisei girl in prison apparently is taken from her own letter. An article titled, "Canadian Girl is Proud About the Way Nisei Can Take It," is taken from a Canadian newspaper (1942). This hodgepodge of stories construct a pastiche of mainstream culture and of Japanese American culture, primarily for a Japanese American community.

As is true in the story of "Miss" Tsuyama, the emphasis on young women's physical beauty is highlighted, often times to the ignorance of women's resistance. In an August 6,1942, article titled "Japanese Girl Found Hiding in Milpitas," Midori Murokita in San Jose is referred to as a "Nisei girl." She is said to be awaiting federal charges in a San Jose jail after refusing to "evacuate." In this story, though she is a woman, she is nonetheless a "girl" (p. 1). ${ }^{27} \mathrm{Emphasis}$ is placed on her vulnerability and her innocence as a "girl" while displacing the fact that she is actively resisting incarceration.

On July 16,1942, another article shows this trend. The article, "Nisei Girl Files Suit, Charging Illegal Detention," the first article about Mitsuye Endo, whose court case against the U.S. government was the first Japanese American case to challenge the "evacuation orders" and win, suggests that she was being held illegally in detention centers: "Miss Endo, charged through her attorney, that she has been deprived of her property rights and that she has been the victim of unjust discrimination" (p. 1). ${ }^{28}$ In addition to being a figurehead for Japanese American loyalty, Endo is depicted as a hardworking, clean-cut, competent Japanese American woman. Her marriage status is highlighted ("Miss" Endo), and though this is a story about how she is confronting the judicial system, she, herself, is the agency through which her attorney from the American Civil Liberties Union is acting. This article borrows information from national, hegemonic newspapers that represented Endo's trial, and in so doing, creates a pastiche of dominant culture for the articulation of oppositional heroinism by an Asian American woman. 
These two examples depict the malleability of women and the transitional ground upon which women rest. Endo's case allows us to see the possibility for pastiche and shows us the way in which pastiche can operate to create a culturally specific discourse. These representations illustrate, however, not how representations of women are liberatory, but how women become passive subjects across which action and articulation of Japanese American heroism can be made. Women are used to tell stories about men. Women are depicted as children rather than as resisters, setting up a rhetoric in which the feminine subject, the rhetorical construction of women, is defined by her vulnerability. "Woman," in this example, is just one way the Pacific Citizen defines what woman is. Thus, "woman" is redefined and reconstructed - put in a perpetually transitional state of existence. The transitional woman is essential to the story the Pacific Citizen tells about the war because her malleable character and body are necessary in order for actions to be made across her.

In addition to constructing a discourse of women's vulnerability, the Pacific Citizen valorizes women's self-consciousness and emphasizes their emotional malleability. Women's subjectivity is defined according to their complacence and their ability to endure physical, emotional, and intellectual hardships without showing external, physical signs of suffering. Ann Nisei appeals to her readers to participate in "morale-building" strategies that would ostensibly help diminish the understandable and predictable despair women suffer in prison. Simultaneously, women's subjectivity is defined by their caretaking role, which also will help them to endure prison while hoping for a quick end of the war and their quick release. This rhetorical therapy invites women to concern themselves with others rather than act out their despair through political protest or resistance. The construction of women's self-consciousness in the articles parallels the physical constructions of the concentration camps. While the newspaper encourages women to take care of their families and be on the lookout for family brooding, a watchguard in a tower stands above the prison camp positioning Japanese American children, women, and men as objects of the gaze. This self-consciousness assumes a malleability of Japanese American women's subjectivity and a connected, though not explicitly stated, resiliency in their morale.

Oyama (1943) argues that concentration camps are not survivable, but she simultaneously calls for faith in the system that makes it unsurvivable. Additionally, she calls for faith in a system that denies Japanese Americans democratic freedoms. Rather than encouraging women to resist domination, express anger and frustration, and organize politically, Oyama tells Japanese Americans to be "pacific" Japanese American "citizens." Oyama tows the ideological line of the JACL and the Pacific Citizen; she joins in the construction of a servile subject, a subject willing to make every sacrifice, even if sacrifice may lead to death. Though her discourse is empathetic to a degree that very little Pacific Citizen reporting approaches, it nevertheless encourages Japanese American subjects to wait the war out and endure whatever pain may result.

Finally, the newspaper emphasizes women's political and economic roles and thereby constructs the "woman in transition" as the ideal embodiment of Japanese American subjectivity. The newspaper uses stories about women's complicity with the war effort and their assimilability as taglines to other stories; thus, women become the agency through which the Pacific Citizen articulates a 
narrative about patriotic support for the War. Such juxtaposition of images of the dangerous, deceptive, and "disloyal" men protesting against the backdrop of the peaceful, hard-working women concentrating on the tasks at hand ultimately serves the purpose of showing women as nonresistant, trustworthy, working subjects of the state. Interestingly, such a depiction might be read resistantly as arguing that physical protest is a masculine trait, and women's choice to work rather than protest (i.e., through a construction of femininity) should be idealized. However, the overall construction of representations of women within the Pacific Citizen sought to use women as ideal "passive" and submissive subjects in order to allow oppressive governmental imprisonment, surveillance, discipline, punishment, and indoctrination to continue unabated. Together with their sexualized and orientalized image as "pin-up queens," women enter the discourse of the Pacific Citizen only as agency for conveying support for the war machinery. In addition, because such articles fail to give faces or individualized identities to the people in these narratives, women are essentially dehumanized, and their subjectivities become tokens used by the JACL to alter the perceptions of Japanese Americans made by white society. These representations function as stereotypes, not as broader descriptors of complex cultural relations, practices, and behaviors. The Pacific Citizen uses women as icons, or "limit-texts," of how passive Japanese Americans should be during World War II by constructing passive women as idealized subjects.

The Pacific Citizen syncretically represents Japanese American women, sometimes through pastiche, by constructing appeals both to a mainstream and Japanese American audience. The focus of the Pacific Citizen on showing how Japanese Americans were good, "pacific" citizens primarily for a mainstream audience and the focus on showing ideal Japanese American subjects for emulation by a Japanese American audience work hand in hand to construct an appeal, counter-hegemonic to mainstream culture but nonetheless supportive of dominant ideology. Yet, in characterizing women as malleable, and using that malleability to placate white society, the discourse upends the cultural syncretic aspects of their depiction. While the Pacific Citizen had the positive potential to draw Japanese Americans together around a common identity during World War II, that identity was structured around and through a sexist and ultimately disempowering image of women. Depictions of women's bodies, emotions, and economic/political roles are not ends in themselves; they are transitional moments along which a larger ideological discourse is constructed.

\section{CONCLUSION}

Our purpose in this study has been to articulate a theory of the critique of vernacular discourse, a critique that might contribute to the broader field of rhetorical studies while simultaneously creating a socially effective critical rhetoric for the construction of a broad-based critical orientation within a multicultural society. We call for rhetoricians to begin to study vernacular discourse with a critical eye and to attempt to forge the beginning of such a critical orientation toward the study of vernacular discourse that even cultural studies is just beginning to enact. We are not merely suggesting that rhetoricians recover texts that have not yet been discovered but rather we suggest that the critique of vernacular discourse may, in fact, become the central focus of critical rhetoric in 
the future. Through the examination of vernacular discourse, new critical approaches and orientations may become possible. The study of vernacular discourse allows us to reconceive the project of the critique of domination and freedom in ways that revise the project altogether.

Through an analysis of representations of women in the Pacific Citizen (19421945), we have been able to demonstrate how a critique of vernacular discourse allows us to recognize the syncretic (protesting and affirming) aspects of such discourse. Additionally, through the displacement of canonical and essentializing positions, we see the multiple ways in which women's identities are constructed, sometimes through pastiche. Unfortunately, such syncretic representations do not necessarily offer an overall liberatory image. Inevitably, in the Pacific Citizen, women are encouraged to be servile agents of the state. This example of vernacular discourse helps us to understand how discourses produce complex representations within specific cultures-representations that mediate power relations, which are not simply unidimensional.

Moreover, our analysis suggests that culturally specific constructions of women are used to liberate the community as a whole, at the expense of women and men within the community. Thus, while the newspaper discusses women's resistance within the culturally specific realm of Japanese American culture, women nonetheless become the agency through which their own freedom is articulated. Further, women take on the least resistant positions of writing letters in attempting to change social conditions. Femininity is therefore reinscribed onto women, who are already constructed doubly as nondominant first in relation to the state that imprisons them and then in relation to Japanese American men, who struggle more masculinely toward political freedom.

Our study enhances the critical process by moving the emphasis away from a focus on hegemonic to vernacular discourses. Our investigation also reveals the fact that by putting emphasis on displacing essentialisms, a critique of vernacular discourse can begin to illustrate how constructions are not necessarily, because they are vernacular, liberatory. In fact, as is evidenced by our analysis, the construction of women uses malleability and infantilization to call for greater support of the war, in addition to less discrimination against Japanese Americans. Just as Japanese Americans are constructed in ways that reconstruct hegemonic relations, African American constructions are often constructed toward a similar end. This conclusion refutes discussions within cultural studies that have assumed that once we studied vernacular discourse, only liberatory effects would be observed. As Wallace (1992) has written:

While I am enjoying the increasing visibility of blacks on TV and in films as much as anybody else, I feel compelled to remember the downside: material conditions are not changing for the masses of blacks. Moreover, it may even be that the economic and political victimization of the urban and rural black poor in the U.S. worldwide is somehow exacerbated by the deeply flawed and inadequate representations of "race" currently sponsored by both blacks and non-blacks in both "high" and "low" culture. (p. 654)

Our discussion here suggests that Wallace is correct to suggest representation, itself, may be partially, if not largely, to blame for the poor material conditions available to most African Americans.

Socially, Japanese American rhetoric in the Pacific Citizen asks Japanese American women to be vulnerable, remain servile, deny their own suffering, 
protest only by writing letters, and remain hard-working automatons for the state. Our approach to these constructed subject positions necessitates an understanding of a critical apparatus that remains skeptical of representation within vernacular discourse while at the same time does not misrecognize its effects as parallel to that of dominant discourse. We believe, as Wallace (1992) does, that not only African American feminism, as she suggests, but cultural studies in general, "all but entirely lacks an analytical and/or self criticalsphere" (p. 654). Without a conscience that attempts to displace rigid representations, no further understanding of the vernacular can be accomplished.

We are not arguing that all vernacular discourses are the same. Nor are we suggesting that Japanese American discourse is the same as African American discourse. We have attempted to contextualize our discussion of Japanese American discourse by specifying historical conditions and by locating our study within the specific location of the Pacific Citizen. Cultural specificity means that analyses of other vernacular communities will necessitate contextualization and erudition in ways we cannot predict before an understanding of cultural productions, relations, and practices are understood. Even some scholars who are deeply committed to multiculturalism and cultural diversity have not gone the route we are suggesting, the route of total immersion into cultural discourses, with appropriate care and respect, with a recognition that study itself is and can be appropriative, with an understanding of pastiche and cultural syncretism, and with a self-critical and conscious commitment toward displacement.

This study allows for the possibility of a shift in rhetorical and cultural studies generally. That shift necessitates that we as critics self-consciously move away from studying objects that historically have seemed for most of us the most appropriate to examine. Rather than analyze solely canonical speechesdiscourse on the nightly radio news, nightly TV news, or in large daily newspapers-and rather than focus solely on the way in which women's subject positions are constructed on prime time television or even in major speeches given by women in public arenas, this study suggests that a more radical move toward the study of vernacular discourse that has been neglected within the field of rhetorical studies may be necessary to conduct a serious treatment of culture. This is not to suggest that size and distribution of publications should be the measure of vernacular media; nor is it to suggest that local, community media groups cannot have large audiences. What we are suggesting is that the focus on national media conglomerates that attempt to reach the largest audiences should not be the sole focus of critical studies. Moreover, with this study, we argue that a critique of vernacular discourse-discourse that emanates from specific localized communities-may be necessary to create a more effective and socially palpable rhetoric. We are not simply calling for more anthologies, though they are clearly needed, and we are not saying that refocusing on talk is enough. The critique of vernacular discourse takes us further than that. It emphasizes a critical orientation toward discourse that puts into question the very concept of marginalization while asking rhetoricians to refocus their mode of inquiry toward localized discourses through which cultural discourse is coordinated. The step we take is to focus attention on vernacular discourse, a refocus that necessitates a critical orientation as a means toward reconceptualization. 
This investigation is merely a prolegomenon and does not make bold conclusions about vernacular discourse broadly. Instead, we focus on a specific cultural construction, that of Japanese American women, within a Japanese American newspaper, as one example of this kind of critical rhetoric. Our purpose in this essay is to refigure the grounds on which rhetorical studies are conducted by expanding the potential sites from which rhetorical critics draw their arguments. But in examining vernacular discourse, we are not suggesting that rhetorical tools be applied, without amendment, to the study of culture. Rather, we are suggesting that new tools and new critical capacities will be shaped as a result of such studies. Rhetoricians cannot take the tools they have now and blithely apply them to the study of cultures. Rather, new methods, approaches, orientations, even attitudes, toward cultures need to be created. This means that the critique of vernacular discourse is not merely an addendum or an example of critical rhetoric. It means that critical rhetoric must be reconceived in light of the vernacular discourse that challenges approaches founded within Western notions of domination, freedom, and power.

We recognize that rhetorical criticism has ventured this route to some degree in the past, primarily through post-1960s protest rhetoric studies (especially studies of black power). However, our study makes several contributions that earlier studies of vernacular discourse were not able to make. First, our study delineates a critical way to discuss issues of gender and power that was not generally the focus of the original studies. Second, we add two dimensions to the conclusions of those studies: (a) that self-reflective criticism must, as a purpose, attempt to destabilize any possible essential or canonical representations of vernacular cultures, and (b) that studies of vernacular discourse will not, by virtue of their being vernacular, lead to broad-based liberatory effects. Third, we argue that the critique of vernacular discourse must be conducted with the idea in mind that without an examination of rhetoric of those struggling to survive, no significant social statements can be made about political, social, and cultural liberation. Finally, we argue that it is not a matter of simply adapting rhetorical criticism by focusing on vernacular cultures with the same methods we have used in the past, but rather that as a result of such studies, the entire rhetorical project may be reshaped.

By recognizing that vernacular discourse is culturally syncretic, and may be generated from a pastiche of hegemonic culture, we begin to realize that vernacular discourse cannot be examined as bits and pieces of hegemonic culture itself but, instead, should be analyzed as a whole new hybrid, through its own conditions of emergence. Studies of vernacular culture may force us to examine figures of discourse not according to specific time periods or genres and not according to historical achievements, embarrassments, or acts. We may have to begin the critical practice by asking how an object or set of objects impacts localized communities. The emphasis on community relations does not allow for examination of texts, sans context. This focus allows for a culturally specific approach to discourse that impacts the formation of specific textual moments. Further, in attempting to acknowledge the cultural specificity of texts, it forces critic and reader alike to note the ways in which texts are often constructed apart from solely hegemonic or counter-hegemonic considerations. Vernacular discourses, even when primarily hegemonic, as in the ex- 


\section{ample illustrated here, still emerge with interests of the vernacular community in mind.}

\section{ENDNOTES}

${ }^{1}$ Despite the fact that King spoke within an African American vernacular and the Gettysburg Address was not widely heard on first reading, both speeches are part of the grand oratorical tradition, and both are anthologized texts available within a broad discursive domain.

"The "critical rhetoric" perspective was first advanced by McKerrow (1989) and has been further articulated in McGee (1990), Charland (1991), Hariman (1991), McKerrow (1991), Ono and Sloop (1992), Gaonkar (1993), and McKerrow (1993). For McKerrow, critical rhetoric is an orientation toward criticism in which critics engage in the critique of domination, which is the critique of those in power, and the critique of freedom, which is critical self-reflection. Sebberson (1990) has also addressed critical rhetoric in another context.

${ }^{3}$ Within the rhetorical tradition, attempts to counter the traditional discussion of public discourse have encouraged both rhetorical and ethnographic alternatives to studies of dominant discourse. Philip Wander (1984) discusses an oppressed "third persona," one ignored by the text and existent outside of it, needing to be located. Maurice Charland (1987) writes that publics are constituted in, through, and by discourse in his study of the Peuple Quebecois. Ethnographic studies suggest that local ethnic communities are in need of analysis. For instance, Gerard Philipsen (1975) seeks to describe the particular way men in Teamsterville speak within their communities. After a study in 1969 of African American males in a Harrisburg ghetto (Richard B. Gregg, A. Jackson McCormack, and Douglas J. Pedersen), Richard Gregg (1971) posited that "black power" rhetoric has an ego-function, that its primary appeal "is to the protestors themselves, who feel the need for psychological furbishing and affirmation" (p. 74). Dwight Conquergood (1991) criticizes the practice of positivist anthropologists who he says "colonize" the "savages." Further, within the field, many scholars have conducted post-1960s studies of the rhetoric of black power [e.g. John W. Bowers and Donovan J. Ochs (1971), Gronbeck (1973), Van Graber (1973)]. More recently rhetorical critics have examined vernacular discourses (while not calling them such). These studies, though working from a similar premise as our own, have not endeavored to construct the larger theoretical project we are forwarding. Richard Morris and Philip Wander (1990), and Randall Lake (1991) have recently presented two examples of contemporary works that gesture toward such a project. But neither Morris and Wander, nor Lake, have begun a systematic, albeit theoretical, discussion of vernacular discourses. Moreover, though Morris and Wander assert that Native American rhetoric does establish "coalition formation, unification, and mobilization" (p. 175), their focus is almost exclusively on how Native American rhetoric functions to protest actions and policies of dominant society. Hence, they show more about how Native American rhetoric is counter-hegemonic. Lake seeks a theoretical rapprochement between dominant and vernacular discourses. Enrique D. Rigsby (1993), while not calling for a larger analysis of vernacular discourse, does focus attention on African American rhetoric at the local level of Birmingham, Alabama. Rigsby highlights the recovery of texts and calls for new tools of analysis with which to analyze these new texts. Gordon Nakagawa (1990a, 1990b, 1993), while not theorizing vernacular discourses specifically, has recently conducted rhetorical studies of Japanese American discourse.

${ }^{4}$ The Pacific Citizen, the educational and political arm of the Japanese American Citizens League ( JACL), run primarily by Nisei, reports on Japanese Americans from the beginning of the war to the end. Nisei refers to second-generation Japanese Americans. Nisei were born in the U.S. Their parents, the Issei, immigrated to the U.S. but could not become citizens until the mid-1950s. The Sansei are the children of the Nisei, the grandchildren of the Issei. And the Yonsei are fourth-generation Japanese Americans. Originally called The Nikkei Shimin, the Pacific Citizen was first published on October 15, 1929. After Pearl Harbor, by June 4, 1942, when almost all Japanese Americans on the West Coast had been incarcerated, the Pacific Citizen, published monthly since the middle of the Depression, began publishing weekly. We are not suggesting that the Pacific Citizen was the only Japanese American newspaper during the time period to construct representations of Japanese American women. To the contrary, the Pacific Citizen was merely one example of a larger construction, but it was an important one, because it stood at the nexus between the U.S. government and Japanese America and later became, through the JACL, one of the primary means by which government understood how World War II affected Japanese Americans.

${ }^{5} \mathrm{We}$ are claiming here that despite theoretical claims concerning decentered, politicized bodies, poststructural criticism often forgets the "lived experience" of the political subject. In other words, we are discussing poststructural criticism as it is often practiced, not necessarily as it is theorized.

${ }^{6}$ For McKerrow, the critique of domination is a critique of discourse of oppression. It assumes discourse and power flow from top to bottom. The critique of freedom, in McKerrow's (1989) work, is a critical orientation of never-ending skepticism. While our approach may in fact seem similar to the critique of freedom, and may fit nicely within McKerrow's paradigm, the shift toward the critique of vernacular discourse entails reconceiving the entire issue of the critique of freedom. As Dilip Gaonkar (1993) has recently noted, because McKerrow is so intent upon derailing all attempts to rethink rhetoric 
as a form of "reasoning" (a la Habermas, Perelman, Toulmin), his theorization of the critique of freedom reads mostly as an attempt to place it in opposition to traditional Western conceptions of reasoning but ignores multiple theoretical moves to discuss a multivocal character of reasoning (p. 150). Nonetheless, this remains far too psychological and focused on the critique of Western rationalism, an inclination from which we would like to move away. It is important for us here to suggest that the critique of vernacular discourse does not entail, either essentially or primarily, the critique of Western rationality. While that may be an effect, or "influence," we suggest that in moving to a critique of vernacular discourse, the very theoretical and philosophical basis for establishing a critical approach must be conceived from the levels of marginal ontology implied by the term, "vernacular."

${ }^{7}$ The distinction we draw here between descriptive/recuperative/appreciative/anthological texts and a critical framework suggests a division between topoi, locations of objects, and techne, the means by which we conduct analyses. Our move is to radically engage both topoi and techne as interrelated objects of critical scrutiny.

${ }^{8}$ The journal Callalloo, a journal that takes a critical approach to the study of African American discourse, is an excellent text with which rhetoricians can begin to think about understanding specific cultural discourses within the academy.

${ }^{9} \mathrm{We}$ do not mean to suggest that African American and Japanese American discourse are the same. Nor do we assume that each discourse can be examined in the same way. However, the goal of the critique of vernacular discourse can be achieved with marginality and locality as the basis for establishing a critical paradigm that opens up possibilities for the articulation of the uniqueness of specific cultural groups, and a paradigm that does not limit those possibilities. Moreover, because of the specificity of historical and social conditions, understanding of multiple groups from a variety of subject positions is needed.

${ }^{10}$ Traditional scholarship about culture tends to support such a reading of vernacular discourses. Robert Park (1904) wrote, "In general it is the same with groups as with individuals: they attain self-consciousness only by opposing other groups. The concepts they form of themselves are always interlaced with images of other groups" (p. 51). To Park, disenfranchised, oppositional groups construct an identity in reciprocal relationship to dominant images of subjectivity. Similarly, Frantz Fanon (1967) indicates in Black Skin, White Masks, that Blacks will experience self-hatred and inferiority because of an overidentification with white culture and a consequential undervaluation of black culture. Self-hatred grows out of the experience of having to live in both black and white cultures as a necessary part of survival and of constantly being inundated with messages that white is good and black is bad. Fanon (1967) writes, "The black man has two dimensions. One with his fellows, the other with the white man. A Negro behaves differently with a white man and with another Negro. That this self-division is a direct result of colonialist subjugation is beyond question" (p. 17).

Though Park and Fanon are correct that a dual consciousness is constructed as a result of having to live in two distinctly different cultures, we argue that rather than view themselves through "images of other groups," that is through representations created by dominant culture, vernacular cultures radically alter the symbolic and signifying means by which cultural images are formed. Instead of representations of people based on stereotypes, vernacular discourse constructs images of vernacular culture with an understanding of how that image might affect communities. Such a thesis takes Richard Gregg's (1971) argument that African Americans construct messages as affirmation of African American identity through the "ego-function of rhetoric" one step further. As social psychologist Beverly Greene (1990) explains: "The task of the Black family is to prepare its children to live among white people without becoming white people, and to mediate between two often contradictory cultures" (p. 214). Greene's analysis indicates that vernacular discourse more significantly constructs a discourse of socialization that makes its way into the daily lives and behaviors so profoundly as to affect the "practice of everyday life." The construction of African American identity, then, is constructed within the context of African American culture. The mediation between parent and child necessitates an ability to signify and symbolize in complicated ways that enable communities to exist within a pastiche of self-defined culture (Gates, 1988, p. 121).

"Though Boyd (1991a, 1991b) does not quote Audre Lorde (1984, pp. 110-113) directly, her argument that communities need to be defined and empowered from within rather than from above in order to assert their interdependence is implied in his argument.

${ }^{12}$ Boyd's theoretical move is similar to that of Cornel West (1988), who argues that in beginning to speak about African Americans, it is necessary to maintain the critical edge of Marxism but to guarantee the cultural specificity of African American culture in doing so. West (1988) writes:

The specificity of the various manifestations of European oppression of African peoples in particular countries is constituted by detailed historical analyses that enact the three methodological moments. Needless to say, these concrete analyses must be ensconced in the particular culture, heritage, and economic history of the Africans and the nation of which the Africans are participants and victims. (p. 22)

For West, one cannot begin to talk about representations of African Americans without recognizing the specific social, historical, and political effects that slavery has had on African American communities up to the present. 
${ }^{13}$ It makes sense here to talk about hegemony in the way that Stuart Hall (1982) does in his discussion of Gramsci. Hall sees dominance as a complex construction of consent by the dominant and cultural leadership to reproduce dominant mores and beliefs to favor "the development and expansion of the dominant social and productive system of life as a whole" (p. 85). Hegemony is constituted "by means of winning the active consent of those classes and groups who were subordinated within it" by leadership so that once consent is attained, newly fashioned class beliefs are seen as natural (p. 85). We purposefully talk about hegemony in this way, rather than the way Laclau and Mouffe (1985) define hegemony (as a mechanism with which leftist political struggle can be conducted), so as to highlight the specific relationship between vernacular and hegemonic culture.

${ }^{14}$ The DJ scratches an album with the needle with one hand, while twisting the album back and forth with the other. Contemporary scratching is often computer generated, via synthesizer, though local rap maintains the original practice.

${ }^{15}$ Henry Louis Gates (1988) notes that vernacular discourse operates both as parody and as parody of parody. In his examples, dominant appropriations of African American dialects in bulletins parody African American vernacular language, but African American vernacular discourse counters such appropriations through the parody of dominant discourse's parodic style (p. 94).

${ }^{16} \mathrm{We}$ owe a debt in this discussion of jazz as an example of vernacular discourse, as well as the explicit reference to Wynton Marsalis, to discussions with Todd Boyd.

${ }^{17}$ Homi Bhabha (1992) suggests that there is an in-between space, a "time-lag" (p. 59), a lapse, or location, where the construction of new subjectivities within language can be constructed. Through reinscription of the subject onto discourse, a "contestation of the given symbols of authority that shifts the terrain of antagonism" (p. 63) can occur.

${ }^{18}$ This attitude persists even in recent works in cultural studies. In his We gotta get out of this place, Lawrence Grossberg (1992) notes that: "Given that some groups are effectively silenced, part of the political responsibility of those empowered to speak may be that they speak for-represent-others" (p. 369).

${ }^{19}$ See specifically Masaoka and Hosokawa (1987), Hosokawa (1969), and Hosokawa (1982).

${ }^{20}$ Examples of biographies available are Modell (1973), Kikumura (1991), Kikumura (1981), Kogawa (1981), Masaoka and Hosokawa (1987), Nomi (1991), Okubo (1946), Sone (1953), Uchida (1982), Wakatsuki Houston and Houston (1973), Yamada (1976), and Yamamoto (1988).

${ }^{21}$ For further primary resources, look at bibliographies in Glenn (1986), Nakano (1990), and Weglyn (1976).

${ }^{22}$ It is important to note that in calling the Pacific Citizen a vernacular newspaper, we are not suggesting that this newspaper contains "authentic" information about Japanese Americans during this time period. Yes, there was censorship because during the War Japanese Americans were suspected of treason and espionage, but the best evidence suggests that the Pacific Citizen engaged more in "self-censorship" rather than being censored by a heavy-handed government (Omura, 1989). The Pacific Citizen is a vernacular paper because it was run by Japanese Americans and because Japanese Americans read the newspaper for information before, during, and after the war. The question of authenticity, we argue, is irrelevant to the constructions of the newspaper, just as we would not expect the New York Times to construct images of Japanese Americans that were somehow authentic of the culture.

${ }^{23}$ Representations of Japanese American women in the Pacific Citizen are generally restricted to discussions of the body and aesthetics in regular columns by Ann Nisei, which contain stories of how to dress, decorate apartments, do one's hair, put on make-up, and shop. Ann Nisei's column is the only column in which a woman's voice is represented as serial author in the Pacific Citizen during this time, and her column is only one of four or five regular columns in the paper, in addition to three or four editorial spots in each issue. It is possible that her column was written by a man, but the specific identity of the author is unimportant to us here. As our argument will demonstrate, the author is constructed as a specifically feminine voice speaking to a specifically feminine audience. Her column attempts, primarily, to help Japanese American women assimilate into dominant society by adapting themselves mentally, emotionally, and physically to new and harsh conditions. It is interesting to note that the name, "Ann Nisei," represents every woman, every Nisei woman. Though she is constructed in the discourse of the Pacific Citizen as a distinctly feminine author, unlike other JACL authors who have double lives as political advocates outside of their news and editorial writing, Ann Nisei does not exist anywhere beyond the columns she writes. Moreover, because much of Ann Nisei's discourse fits so well into the overall ideology of the Pacific Citizen, because the positions she takes never directly confront the arguments of editorial and news writers, and because her columns deal with "women's issues," which are defined within the column as distinctly apolitical, the column is a vehicle for women's assimilation into mainstream culture; it asks them to be happy in their misery, to serve their husbands and children, and to remain faithful to the democratic ideology during wartime. Finally, because Ann Nisei is not mentioned in other columns and stories about JACL writers, her representation is in fact as object, as agent and purveyor of ideology for the purpose of persuading women to remain nonresistant subjects of a Japanese American maledominated culture and of the state.

${ }^{24}$ In a later story, Dillon Myer, head of the War Relocation Authority, explains that the guard was beaten after he first struck a prisoner, and Myer condemns the actions of the injured guard. 
${ }^{25}$ Trinh (1989) suggests that dominant discourse has always depicted woman as other than man. She suggests, therefore, that woman is always a "subject-in-the-making" in these texts (pp. 102-103). A slightly different conclusion may be drawn by examining vernacular discourse. Woman, in these texts, is not simply a binary but rather is a multiplicity of constructions that render woman a composite "subject-in-transition."

${ }^{26}$ The article reads, "Miss Tsuyama, who is 18 and little, is aiding the war effort in still another way in addition to her work of bolstering the morale of the men of the Pacific forces. She is buying war bonds" ("Story of the Week," 1943, p. 3).

${ }^{27}$ While the major feminist critique of the sexist use of words like "girl" as it is applied to adult women takes place in the late 1960 s and early 1970s, from a contemporary standpoint it is essential to criticize such discourse from a present understanding, as such discourse can only be read in the present.

${ }^{28}$ The "charge" that Endo makes was hardly a charge at all. Instead, Endo was used by the American Civil Liberties Union and her lawyer as a passive emblem of a constitutional challenge to imprisonment. This is one of very few articles that features a Japanese American as the active agent of political change, yet it misses the degree to which Endo was in fact a symbol to be used by the legal system. This article begins to show how Pacific Citizen discourse, with an editorial purpose to show the loyalty of Japanese Americans and to praise their accommodationism, is continually discontinuous. Resistance and dissatisfaction within prisons make their way to the surface of the Pacific Citizen, making it difficult for the JACL to bring about unification under an assimilationist program. This fact does not, as one might suspect, call into question the JACL's commitment to assimilation. The fact that articles appear that do not fulfill the purpose of the JACL's program of assimilation merely demonstrates the difficulty in constructing a specific appeal through the medium of a "news" paper.

\section{REFERENCES}

Baker, H.A. (1984). Blues, ideology, and Afro-American literature: A vernacular theory. Chicago: University of Chicago Press.

Baker, H.A. (1989). The promised body: Reflections on canon in an Afro-American context. In P. Hernadi (Ed.), The rhetoric of interpretation and the interpretation of rhetoric (pp. 87-104). Durham, NC: Duke University Press.

Bhabha, H. (1992). Postcolonial authority and postmodern guilt. In L. Grossberg, C. Nelson, \& P. Treichler (Eds.), Cultural studies (pp. 56-68). New York: Routledge.

Bowers, J.W. \& Ochs, D.J. (1971). The rhetoric of agitation and control. Reading, MA: Addison-Wesley.

Boyd, T. (1991a). Deep in the shed: The discourse of African American cinema. Iowa Journal of Literary Studies, 11, 99-104.

Boyd, T. (1991b). The meaning of the blues. Wide Angle, 13, 56-61.

Burke, K. (1957). The rhetoric of Hitler's "battle." In The Philosophy of literary form: Studies in symbolic action (164-189). New York: Vintage Books. (Original Work Published 1941).

Burke, K. (1966). Language as symbolic action: Essays on life, literature, and method. Berkeley: University of California Press.

Butler, J. (1990). Gender trouble: Feminism and the subversion of identity. New York: Routledge.

Canadian girl is proud about the way Nisei can take it. (1942, July 30). Pacific Citizen, p. 5.

Charland, M. (1987). Constitutive rhetoric: The case of the Peuple Quebecois. Quarterly Journal of Speech, 73, 133-150.

Charland, M. (1991). Finding a horizon and telos: The challenge to critical rhetoric. Quarterly Journal of Speech, 77, 71-74.

Conquergood, D. (1991). Rethinking ethnography: Towards a critical cultural politics. Communication Monographs, 58, 179-194.

Deleuze, G. \& Guattari, F. (1986). Kafka: Toward a minor literature (D. Polan, Trans.). Minneapolis: University of Minnesota Press.

Despondency over evacuation drives woman to suicide. (1942, July 23). Pacific Citizen, p. 8.

Fanon, F. (1967). Black skin, white masks (C.L. Markmann, Trans.). New York: Grove Weidenfeld.

Fire college for girls started at Manzanar. (1943, April 8). Pacific Citizen, p. 1.

First Nisei girl accepted for service in WAAC. (1943, July 3). Pacific Citizen, p. 1.

Five-day disturbance ended at Poston; Loyal Nisei win praise of project director. (1942, November 26). Pacific Citizen, p. 1.

Gaonkar, D.P. (1993). Performing with fragments: Reflections on critical rhetoric. In R.E. McKerrow (Ed.), Argument and the postmodern challenge: Proceedings of the eighth SCA/AFA conference on argumentation (pp. 149-155). Annandale, VA: SCA.

Gates, H.L. (1988). The signifying monkey: A theory of African American literary criticism. New York: Oxford University Press.

Glenn, E.N. (1986). Issei, Nisei, warbride: Three generations of Japanese American women in domestic service. Philadelphia: Temple University Press. 
Greene, B. (1990). What has gone before: The legacy of racism and sexism in the lives of black mothers and daughters. Women and Therapy, 9, 207-230.

Gregg, R.B. (1971). The ego-function of the rhetoric of protest. Philosophy and Rhetoric, 4, 71-91.

Gregg, R.B., A.J. McCormack, \& D.J. Pedersen. (1969). The rhetoric of black power: A street-level interpretation. Quarterly Journal of Speech, 55, 151-160.

Gronbeck, B.E. (1973). The rhetoric of social-institutional change: Black action at Michigan. In G.P. Mohrmann, C.J. Stewart, \& D.J. Ochs (Eds.), Explorations in rhetorical criticism (pp. 96-123). University Park: Pennsylvania State University Press.

Grossberg, L. (1992). We gotta get out of this place: Popular conservatism and postmodern culture. New York: Routledge.

Hall, S. (1982). The rediscovery of 'ideology': Return of the repressed in media studies. In M. Gurevitch et al. (Eds.), Culture, society and the media (pp. 56-90). London: Methuen.

Hariman, R. (1991). Critical rhetoric and postmodern theory. Quarterly Journal of Speech 77, 67-70.

Hosokawa, B. (1969). Nisei: The quiet Americans. New York: William Morrow.

Hosokawa, B. (1982). JACL: In quest of justice. New York: William Morrow.

Houston, J.W. \& Houston, J.D. (1973). Farewell to Manzanar: A true story of Japanese American experience during and after the World War II internment. New York: Bantam.

In defense of cause of Nisei. (1942, March 1). Pacific Citizen, p. 4.

Jameson, F. (1992). Postmodernism, or, the cultural logic of late capitalism. Durham, NC: Duke University Press.

Japanese girl found hiding in Milpitas. (1942, August 6). Pacific Citizen, p. 1.

Kikumura, A. (1981). Through harsh winters: The life of a Japanese immigrant woman. Novato, CA: Chandler \& Sharp.

Kikumura, A. (1991). Promises kept: The life of an Issei man. Novato, CA: Chandler \& Sharp.

King, M.L., Jr. (1963, August 28). I have a dream. Speech delivered at Lincoln Memorial, Washington, D.C.

Kogawa, J. (1981). Obasan. Boston: D.R. Godine.

Laclau, E. \& Mouffe, C. (1985). Hegemony and socialist strategy: Towards a radical democratic politics. London: Verso.

Lake, R.A. (1991). Between myth and history: Enacting time in Native American protest rhetoric. Quarterly Journal of Speech, 77, 123-151.

Lincoln, A. (1863, November 19). An address given at Gettysburg, $P A$.

Lorde, A. (1984). The master's tools will never dismantle the master's house. In Sister/outsider: Essays and speeches by Audre Lorde (pp. 110-113). Freedom, CA: Crossing Press.

Marsalis, W. (1986, February). Why we must preserve our jazz heritage. Ebony, pp. 131-136.

Masaoka, M. \& Hosokawa, B. (1987). They call me Moses Masaoka: An American saga. New York: William Morrow.

McGee, M.C. (1990). Text, context, and the fragmentation of contemporary culture. Western Journal of Speech Communication, 54, 274-289.

McKerrow, R.E. (1989). Critical rhetoric: Theory and praxis. Communication Monographs, 56, 91-111.

McKerrow, R.E. (1991). Critical rhetoric in a postmodern world. Quarterly Journal of Speech, 77, 75-78.

McKerrow, R.E. (1993). Critical rhetoric and the possibility of the subject. In I. Angus \& L. Langsdorf (Eds.), The critical turn: Rhetoric and philosophy in postmodern discourse (pp. 51-67). Carbondale: Southern Illinois University Press.

Modell, J. (Ed.). (1973). The Kikuchi diary: Chronicle from an American concentration camp: The Tanforan journals of Charles Kikuchi. Urbana: University of Illinois Press.

Morris, R. \& Wander, P. (1990). Native American rhetoric: Dancing in the shadows of the Ghost Dance. Quarterly Journal of Speech, 76, 164-191.

Nakagawa, G. (1990a). "No Japs allowed": Negotiation and naming as subject-constituting strategies reflected in contemporary stories of Japanese American internment. Communication Reports, 3, 22-27.

Nakagawa, G. (1990b). "What are we doing here with all these Japanese?": Subject-constitution and strategies of discursive closure represented in stories of Japanese American internment. Communication Quarterly, 38, 388-402.

Nakagawa, G. (1993). Deformed subjects, docile bodies: Disciplinary practices and subject-constitution in stories of Japanese-American internment. In D.K. Mumby (Ed.), Narrative and social control: Critical perspectives (pp. 143-163). Newbury Park, CA: Sage.

Nakano, M.T. (1990). Japanese American women: Three generations, 1890-1990. Berkeley: Mina Press.

Nisei girl files suit, charging illegal detention. (1942, July 16). Pacific Citizen, p. 1.

Nisei girl writes from Idaho jail. (1942, June 11). Pacific Citizen, p. 5.

Nisei girls take jobs in Milwaukee. (1943, March 4). Pacific Citizen, p. 2.

Nisei woman: Hints on making new clothing from old. (1942, July 30). Pacific Citizen, p. 5.

Nisei, A. (1942, June 4). Nisei women: Evacuation brings new problems. Pacific Citizen, p. 5.

Nisei, A. (1942, June 25). Many active at centers. Pacific Citizen, p. 5.

Nisei, A. (1943, March 25). Question of the hour: Shall I leave the center? Pacific Citizen, p. 6.

Nomi. (1991). Nisei odyssey: The camp years. Fountain Valley, CA: Bowder Printing. 
Okubo, M. (1946). Citizen 13660. New York: Columbia University Press.

Omura, J. (1989). Japanese American journalism during World War II. In G.M. Nomura, R. Endo, S.H. Sumida, \& R.C. Leong (Eds.), Frontiers of Asian American studies: Writing, research, and commentary (pp. 71-77). Pullman: Washington State University Press.

Ono, K.A. \& Sloop, J.M. (1992). Commitment to telos-A sustained critical rhetoric. Communication Monographs, 59, 48-60.

Owen, F. (1990, March). Public service. Spin, pp. 57-61, 86.

Oyama, M. (1943, June 24). The long view ahead. Pacific Citizen, p. 6.

Park, R.E. (1904). The crowd and the public and other essays. Chicago: University of Chicago Press.

Philipsen, G. (1975). Speaking "like a man" in Teamsterville: Cultural patterns of role enactment in an urban neighborhood. Quarterly Joumal of Speech, 61, 13-22.

Resettlement program affords opportunity for Nisei women to apply specialized talents. (1943, December 25). Pacific Citizen, p. 18.

Rigsby, E.D. (1993). African American rhetoric and the "profession." Western Journal of Communication, 57, 191-199.

Sebberson, D. (1990). The rhetoric of inquiry or the sophistry of the status quo? Exploring the common ground between critical rhetoric and institutional economics. Journal of Economic Issues 24, 1017-1026.

Sone, M.I. (1953). Nisei daughter. Seattle: University of Washington Press.

Story of the week: Nisei girl is "pin-up queen" of U.S. forces in Pacific. (1943, August 21). Pacific Citizen, p. 3.

Trinh, M. (1989). Woman, native, other: Writing postcoloniality and feminism. Bloomington: Indiana University Press.

Trinh, M. (1991). When the moon waxes red: Representation, gender and cultural politics. New York: Routledge.

Troops impose martial law on Tule Segregation Center. (1943, November 6). Pacific Citizen, pp. 1, 7.

Uchida, Y. (1982). Desert exile: The uprooting of a Japanese American family. Seattle: University of Washington Press.

Van Graber, M. (1973). Functional criticism: A rhetoric of black power. In G.P. Mohrmann, C.J. Stewart, \& D.J. Ochs (Eds.), Explorations in rhetorical criticism (pp. 207-222). University Park: Pennsylvania State University Press.

Victory resolutions: Rules of conduct for women to follow to support U.S. defense efforts. (1942, February). Pacific Citizen, p. 7.

Wallace, M. (1992). Negative images: Towards a Black feminist cultural criticism. In L. Grossberg, C. Nelson, \& P. Treichler (Eds.), Cultural Studies (pp. 654-671). New York: Routledge.

Wander, P. (1984). The third persona: An ideological turn in rhetorical theory. Central States Speech Journal, 35, 197-216.

Weglyn, M. (1976). Years of infamy: The untold story of American concentration camps. New York: Morrow.

West, C. (1988). Marxist theory and the specificity of Afro-American oppression. In C. Nelson \& L. Grossberg (Eds.), Marxism and the interpretation of culture (pp. 17-29). Urbana: University of Illinois Press.

Yamada, M. (1976). Camp notes and other poems. Berkeley: Shameless Hussy Press.

Yamamoto, H. (1988). Seventeen syllables and other stories. Latham, NY: Kitchen Table: Women of Color Press. 